\title{
Reliability of the Hebrew Version of the Integrated Covid-19 Threat Scale
}

Keren Taub ${ }^{1}$, Dekel Abeles ${ }^{2}$ and Shlomit Yuval-Greenberg ${ }^{1,2}$

${ }^{1}$ Sagol School of Neuroscience and ${ }^{2}$ School of Psychological Sciences, Tel Aviv University

Corresponding author: shlomitgr@tau.ac.il

\section{Abstract}

The COVID-19 global pandemic of 2020 brought about a surge of psychological research focusing on its cognitive and emotional impact. In a recent study Kachanoff et al. (2020) published The Integrated Covid-19 Threat Scale - a 10-items scale for measuring the perceived symbolic and realistic threats of COVID-19. We have translated this scale to Hebrew and adapted to Israeli participants. Here we publish this Hebrew version and report its internal and external reliability.

\section{Introduction}

The COVID-19 global pandemic of 2020 brought about a surge of psychological research focusing on its cognitive and emotional impact (Conway III, Woodard, \& Zubrod, 2020; Sood, 2020; Van Bavel et al., 2020). One aspect that is common to many of these studies is their interest in measuring and quantifying the amount of emotional distress caused by this crisis and specifically the amount of perceived threat of the disease and its national and personal consequences.

In a recent study Kachanoff et al. (2020) published The Integrated Covid-19 Threat Scale - a 10-items scale for measuring the perceived threat of COVID-19. For each of the 10 items, participants were requested to rate how much threat, if any, is the coronavirus outbreak to this item. Rating was done on a scale from 1 ("Not a Threat") to 4 ("Major Threat"). Some of the items on the scale represented realistic threats - i.e. concreate attack on physical and material well-being; whereas other items represented symbolic threats - an assault on cultural and national identity (F. Kachanoff, Bigman, Kapsaskis, \& Gray, 2020; F. J. Kachanoff, Kteily, Khullar, Park, \& Taylor, 2019; Stephan, Ybarra, \& Morrison, 2009; Tajfel, Turner, Austin, \& Worchel, 1979). It was suggested by Kachanoff et al. that both types of threats likely increase psychological distress and may predict behaviors differentially. The Integrated Covid-19 Threat Scale is in English and its items are specifically phrased to target North American participants. It includes items such as "what does it mean to be 
American" and "American values and traditions" which need to be adapted to be used in other countries and cultures. As part of a study on cognition and emotion during the COVID19 crisis, we translated the Integrated Covid-19 Threat Scale to Hebrew and adapted it to Israeli participants (e.g. by changing "what does it mean to be American" to "Israeli identity"). Here we report internal and external reliability of the Hebrew version of this scale and compare it to the original version.

\section{Methods}

Participants. We recruited 598 Israeli adult participants as part of a larger scale online study on cognition and emotion during the COVID-19 crisis. Following pre-registered exclusions, 492 participants were included in the study (258 females, ages 18-96, M: 41.15, SD: 14.64). Participation was either voluntary (57 participants) or for a small payment (435 participants). Participants were recruited online through the Israeli internet surveys company Panel4All. Participation was completely anonymous and participants were asked to consent by pressing a key at the beginning of the questionnaire. The study was approved by the ethical committee of Tel-Aviv University.

Time of study. The study was conducted between the $11^{\text {th }}$ and the $19^{\text {th }}$ of April 2020, during the coronavirus outbreak. During this time, the total number of COVID-19 related deaths in Israel increased from 101 (on April $11^{\text {th }}$ ) to 172 (April 19 $9^{\text {th }}$ ). The number of diagnosed cases at this period increased from 10,743 to 13,491 . Israel was at the time under a partial lockdown limiting non-essential travel to no more than 100 meters from residents. School, universities and childcare facilities were closed and business was limited to the essential. Unemployment rate in Israel reached around $25 \%$ at that time.

Demographic and personal details questionnaires. We collected the following demographics and personal details on each participant: age, marital status, number and ages of children, number of people living in the same resident, employment and health status. Participants were also requested to indicate whether they consider themselves to be at a risk-group for the coronavirus.

The Hebrew Version of the Integrated Covid-19 Threat Scale. As the original scale, the Hebrew version includes 10 items describing entities which could be potentially threated by the COVID-19 crisis (see Table 1 for the list of items). Participants were requested to rate 
how much threat, if any, is the coronavirus outbreak to each one of these items. Rating was done on a scale from 1 ("Not a Threat") to 4 ("Major Threat"). The first five statements of the questionnaire refer to symbolic threats to one's socio-cultural identity (national rights and freedom, national identity, national values and traditions, democracy and the maintenance of law and order). The last five statements refer to realistic threats to physical or financial safety (personal health, national health, personal financial safety, national economy and day-to-day life in the local community). The questionnaire was translated to Hebrew with a few adaptations. All statements that originally referred to the American society and values, were rephrase to refer to Israel. The second statement, originally referring to a possible threat to "what it means to be American", was modified in the Hebrew version to "the Israeli identity". Table 1 depicts the items.

Anxiety scale. we used a Hebrew version of The Generalized Anxiety Disorder 7-Item Scale (GAD-7), developed by (Spitzer et al. 2006), which was found to have high values of reliability and validity (Löwe et al., 2008). Participants are requested to rate on a scale of 0 ("Not at all") to 3 ("Almost every day") how often they were troubled by each of the scale's seven items in the past two weeks.

Analysis. Scores of the Hebrew Version of the Integrated Covid-19 Threat Scale were calculated by measuring the mean rating for each participant: overall for all ten items and separately for the five symbolic and the five realistic items. We assessed internal reliability using Cronbach's Alpha, for the full item set and separately for its two parts (symbolic and realistic). We compared the Cronbach's Alpha values of the English and Hebrew scales using the COCRON online tool (Diedenhofen \& Musch, 2016). Mean scores of the English and Hebrew scales were compared using a two-tailed independent samples t-test based on the mean and SD values reported in Kachanoff et al. (2020). Theoretical statistics and factor analysis were calculated and compared with the measurements reported for the original version of the scale in Kachanoff et al. (2020). 


\begin{tabular}{|c|c|c|}
\hline $\begin{array}{l}\text { How much threat, if any, is the } \\
\text { coronavirus outbreak for... }\end{array}$ & & עד כמה, אם בכלל, התפרצות וירוס הקורונה מהווה \\
\hline $\begin{array}{l}\text { The right and freedoms of the U.S. } \\
\text { population as a whole }\end{array}$ & 1 & הזכויות והחופש של כלל אוכלוסיית ישראל \\
\hline What it means to be American & 2 & 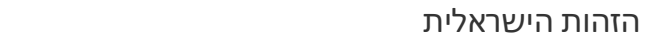 \\
\hline American values and traditions & 3 & ערכים ומסורות ישראליות \\
\hline American democracy & 4 & הדמוקרטיה הישראלית \\
\hline $\begin{array}{l}\text { The maintenance of law and order in } \\
\text { America }\end{array}$ & 5 & השמירה על החוק והסדר בישראל \\
\hline Your personal health & 6 & הבריאות האישית שלי \\
\hline $\begin{array}{l}\text { The health of the U.S. population as a } \\
\text { whole }\end{array}$ & 7 & הבריאות של כלל האוכלוסייה בישראל \\
\hline Your personal financial safety & 8 & הביטחון הכלכלי שלי \\
\hline The U.S. economy & 9 & כלכלת ישראל \\
\hline Day-today life in your local community & 10 & חיי היומיום בקהילה המקומית שלי \\
\hline
\end{tabular}

Table 1: Original questionnaire and the Hebrew translation.

\section{Results}

Reliability. Cronbach's Alpha was high for both English and Hebrew scales, but it was significantly higher for the full English version relative to the full Hebrew version of the scale $\left(\chi^{2}(1)=4.55, p=0.032\right)$ and also higher for the English relative to the Hebrew version of the symbolic threat items $\left(\chi^{2}(1)=11.81, p=0.006\right)$. There was no significant difference in the Cronbach's Alpha among the English and Hebrew realistic threat items $\left(\chi^{2}(1)=0.15\right.$, $p=0.70)$. These results are depicted in Table 2 .

Scores. The mean scores were significantly higher in the English relative to the Hebrew scale (full Scale: $t(836)=6.9, p<0.0001, \% 95 \mathrm{Cl}[-0.36-0.20]$; Symbolic threat items: $t(836)=5.02$, 
$p<0.0001, \% 95 \mathrm{Cl}[-0.36-0.16]$; Realistic threat items: $t(836)=7.13, p<0.0001 ; \% 95 \mathrm{Cl}[-0.39$ 0.22]). These results are depicted in Table 2.

Personal and demographic factors. We compared the scores of participants who considered themselves at risk for the coronavirus $(\mathrm{N}=117)$ and those who considered themselves not a risk $(\mathrm{N}=341)$. Participants who responded that they do not know whether they are at risk or not $(\mathrm{N}=34)$ were not included from this analysis. For all three scales (full, symbolic and realistic) the threat perception scores were higher for the risk group relative to the non-risk group (Table 3). For the full and the symbolic items, this difference was marginally significant (full scale: $t(456)=1.931, p=0.054$; symbolic threat items: $t(456)=1.98, p=0.048$ ), but for the realistic threat items it was non-significant $(t(456)=1.221, p=0.223)$. We additionally compared the scores of males and females. There was a trend for higher scores among females than males (Table 3). This trend was not significant for the full scale (full scale: $t(490)=-1.68, p=0.094$ ) and for the symbolic threat items (the symbolic threat items (symbolic threat: $t(490)=-0.862, p=0.389)$, but it was significant for the realistic threat items $(t(490)=-2.022, p=0.044, \% 95 \mathrm{Cl}-0.231-0.003])$. The scores did not correlate significantly with age (full scale: $r=-0.05, p=0.247$; symbolic threat items: $r=-0.02, p=0.698$; realistic threat: $r=-0.07, p=0.105$ ) or with the number of people living in the participant's resident (full scale: $r=-0.02, p=0.73$; symbolic threat items: $r=-0.01, p=0.767$; realistic threat items: $r=-$ $0.01, p=0.778)$. 


\begin{tabular}{|c|c|c|c|c|c|c|}
\hline & $\begin{array}{l}\text { COVID-19 } \\
\text { Threat - } \\
\text { Full Scale }\end{array}$ & $\begin{array}{l}\text { COVID-19 } \\
\text { Threat - } \\
\text { Symbolic }\end{array}$ & $\begin{array}{l}\text { COVID-19 } \\
\text { Threat - } \\
\text { Realistic }\end{array}$ & Mean & SD & Reliability \\
\hline $\begin{array}{l}\text { COVID-19 } \\
\text { Threat - Full } \\
\text { Scale }\end{array}$ & & & & $\begin{array}{c}2.46 \\
(2.74)\end{array}$ & $\begin{array}{c}0.57 \\
(0.59)\end{array}$ & $\begin{array}{c}\alpha=0.81 \\
(0.85)\end{array}$ \\
\hline $\begin{array}{l}\text { COVID-19 } \\
\text { Threat - } \\
\text { Symbolic }\end{array}$ & $\begin{array}{c}0.86 * * * \\
(0.89)\end{array}$ & & & $\begin{array}{c}2.02 \\
(2.28)\end{array}$ & $\begin{array}{c}0.70 \\
(0.79)\end{array}$ & $\begin{array}{c}\alpha=0.78 \\
(0.85)\end{array}$ \\
\hline $\begin{array}{l}\text { COVID-19 } \\
\text { Threat - } \\
\text { Realistic }\end{array}$ & $\begin{array}{c}0.83 * * * \\
(0.80)\end{array}$ & $\begin{array}{c}0.42 * * * \\
(0.45)\end{array}$ & & $\begin{array}{c}2.90 \\
(3.21)\end{array}$ & $\begin{array}{c}0.64 \\
(0.59)\end{array}$ & $\begin{array}{c}\alpha=0.76 \\
(0.77)\end{array}$ \\
\hline Anxiety - GAD-7 & $0.29 * *$ & $0.21 * * *$ & $0.29 * * *$ & 5.48 & 4.98 & $\alpha=0.91$ \\
\hline Age & -0.052 & -0.02 & -0.07 & 41.15 & 14.64 & \\
\hline $\begin{array}{c}\text { Num. of people } \\
\text { living in the } \\
\text { house }\end{array}$ & -0.02 & -0.01 & -0.01 & 3.80 & 1.68 & \\
\hline
\end{tabular}

Table 2: Reliability, means and correlations ( $N=492)$. The first three rows are based on the data of the Hebrew version of the COVID-19 threat scale. In parenthesis: the equivalent values of the English version based on Kachanoff et al., $2020(N=346)$. The last row represents data of the Anxiety scale (Spitzer et al., 2006). Significance values: ${ }^{*} p<0.05,{ }^{* *} p<.01, * * * p<.001$.

\begin{tabular}{|ccccc|}
\hline & $\mathrm{N}$ & $\begin{array}{c}\text { COVID-19 Threat }- \\
\text { Full Scale }\end{array}$ & $\begin{array}{c}\text { COVID-19 Threat }- \\
\text { Symbolic }\end{array}$ & $\begin{array}{c}\text { COVID-19 Threat }- \\
\text { Realistic }\end{array}$ \\
\hline High risk & 341 & $2.54(0.63)$ & $2.13(0.77)$ & $2.96(0.71)$ \\
\hline Low risk & 117 & $2.43(0.54)$ & $1.98(0.67)$ & $2.88(0.62)$ \\
\hline Female & 258 & $2.50(0.54)$ & $2.05(0.69)$ & $2.96(0.62)$ \\
\hline Male & 234 & $2.42(0.59)$ & $2.00(0.72)$ & $2.84(0.67)$ \\
\hline
\end{tabular}

Table 3: mean scores of the COVID-19 Threat scale according to Risk Group (Yes/No) as reported by the participants, and according to Gender (Female/Male). 
Factor structure of integrated COVID-19 Threat Scale. Following Kachanoff et al. (2020) we performed a principal component analysis on the measured scores. Consistently with the findings of Kachanoff et al. (2020), this analysis revealed a 2-factor solution: one factor with the five items assessing symbolic threat (Eigen Value=3.71, Variance Explained=37.13\%) and one with the five items assessing realistic threat (Eigen Value $=1.58$, Variance Explained=15.77\%). Factor loadings are presented in Table 4.

\begin{tabular}{|c|c|c|}
\hline Item & Symbolic Threat & Realistic Threat \\
\hline 1 & 0.621 & 0.336 \\
\hline 2 & 0.712 & -0.08 \\
\hline 3 & 0.655 & 0.097 \\
\hline 4 & 0.779 & 0.165 \\
\hline 5 & 0.758 & 0.256 \\
\hline 6 & 0.116 & 0.665 \\
\hline 7 & 0.070 & 0.774 \\
\hline 8 & 0.141 & 0.667 \\
\hline 9 & 0.154 & 0.74 \\
\hline 10 & 0.213 & 0.655 \\
\hline
\end{tabular}

Table 4: Varimax rotated factor loadings of a Principle Factor Analysis of the 10-item integrated COVID-19 Threat Scale.

\section{Discussion}

The Hebrew version of the Integrated Covid-19 Threat Scale was found to be internally reliable with high Cronbach's Alpha values, and also externally reliable when correlated with an anxiety scale. However, internal reliability was higher for the English relative to the Hebrew version of the scale.

The mean scores of the two versions were higher for the English than the Hebrew version. The most likely explanation for these differences is the different administration time of the two scales: the English scale was administered on March 19-20 2020 whereas the Hebrew scale was administered almost a month later on April 11-19 2020. March 19th 2020 signaled the beginning of the crisis - as that was the day when California, the first state to issue a stay-at-home order, announced this order. It is possible that threat levels were higher at the beginning, when the unknown situation was overwhelming. By April, distress caused by uncertainty and threat perception may have been slightly reduced. Other explanations for 
this difference in scores could be attributed to cultural differences between the American and Israel populations, or differences between the countries in regulations and the management of the COVID-19 crisis. It is also possible that these differences were due to the translation or cultural adaptation of the scale items.

We conclude that the Hebrew version of the COVID-19 Threat Scale can be used as a reliable index of the perceived threat of the coronavirus among Israelis. It would be an important contribution for future studies to use the different version of this scale to follow the evolvement of threat perception among different populations during this crisis.

\section{Acknowledgements}

This research was funded by the Israel Science Foundation grant 1960/19 to S.Y-G and by the Ariane de Rothschild Women Doctoral scholarship to KT.

\section{References}

Conway III, L. G., Woodard, S. R., \& Zubrod, A. (2020). Social Psychological Measurements of COVID-19: Coronavirus Perceived Threat, Government Response, Impacts, and Experiences Questionnaires. Preprint at DOI: $\underline{10.31234 / \text { osf.io/z2x9a }}$

Diedenhofen, B., \& Musch, J. (2016). cocron: A Web Interface and R Package for the Statistical Comparison of Cronbach 's Alpha Coefficients. International Journal of Internet Science, 11(1), 51-60.

Kachanoff, F., Bigman, Y., Kapsaskis, K., \& Gray, K. (2020). Measuring Two Distinct Psychological Threats of COVID-19 and their Unique Impacts on Wellbeing and Adherence to Public Health Behaviors. Preprint at DOI: 10.31234/osf.io/5zr3w

Kachanoff, F. J., Kteily, N. S., Khullar, T. H., Park, H. J., \& Taylor, D. M. (2019). Determining our destiny: Do restrictions to collective autonomy fuel collective action? Journal of Personality and Social Psychology. DOI: 10.1037/pspi0000217

Löwe, B., Decker, O., Müller, S., Brähler, E., Schellberg, D., Herzog, W., \& Herzberg, P. Y. (2008). Validation and standardization of the Generalized Anxiety Disorder Screener (GAD-7) in the general population. Medical Care, 266-274.

Sood, S. (2020). Psychological effects of the Coronavirus disease-2019 pandemic. Research \& Humanities in Medical Education, 7, 23-26.

Spitzer, R. L., Kroenke, K., Williams, J. B. W., \& Löwe, B. (2006). A brief measure for assessing generalized anxiety disorder: the GAD-7. Archives of Internal Medicine, 166(10), 10921097. 
Stephan, W. G., Ybarra, O., \& Morrison, K. R. (2009). Intergroup threat theory. In Handbook of prejudice, stereotyping, and discrimination. (pp. 43-59). New York, NY, US: Psychology Press.

Tajfel, H., Turner, J. C., Austin, W. G., \& Worchel, S. (1979). An integrative theory of intergroup conflict. Organizational Identity: A Reader, 56, 65.

Van Bavel, J. J., Boggio, P., Capraro, V., Cichocka, A., Cikara, M., Crockett, M., ... Drury, J. (2020). Using social and behavioural science to support COVID-19 pandemic response. Nature Human Behavior 